\title{
Prevalence of Opportunistic Infection and Associated Pregnancy Complication among HIV Positive Women Delivering in Tanzania
}

\author{
Article by Admirabilis Kalolella \\ Dar es salaam, Tanzania \\ E-mail: kalolella@hotmail.com
}

\begin{abstract}
Objective: The objective of this study was to assess the prevalence of opportunistic Infections (OIs) and associated pregnancy complication among HIV Positive women giving birth in hospitals of Dar es salaam, Tanzania.

Design: The cross sectional study design using OIs checklist was used to collect data among 105 participants. The Epi Data software was used for data entry. The complete data set was later transferred to SAS version 9.4 for data analysis and interpretations. The associations of categorical variables were determined by the Chi-squire test, in which, p-values $<0.05$ were considered as significant association.

Result. Among 105 participants, 63(60\%) of them were diagnosed with OIs, while 42(40\%) did not show any symptoms of OIs. The most common OIs symptoms reported were; frequently fatigue 46(43.8\%), Persistent profuse night sweats 43(40.9\%), Persistent muscle aches 41(39\%), and unexplained recurring fever 39(37.1\%). Participants with recurrent memory loss, depression and neurological disorders had more 5(20.8\%) babies born with body weight below 2500g, underweight baby, compared to 5(6.1\%) women without these symptoms, P-Value <0.0316. Participants without recurrent severe pneumonia, 24(35.2\%), which is among the late HIV stage OIs (WHO clinical stage 3 \&4) are slightly protected to developed vaginal tears during birth compared to those 7 (18.9\%) with recurrent severe pneumonia. P-Value <0.0693.

Conclusion. In conclusion, the majority of HIV infected pregnant women giving birth suffer from OIs. Recurrent memory loss, depression and neurological disorders and recurrent severe pneumonia are risk factors for pregnancy complication
\end{abstract}

Keywords: HIV infected pregnant women, Opportunistic infection, pregnancy complication underweight baby, neurological disorders, vaginal tear, ARV.

\section{Introduction}

Opportunistic infections (OIs) are severe infectious diseases that are persistent and recurrent which manifest among HIV infected person due to immune-suppression, and they are main clinical complaints. The Human immunodeficiency Virus (HIV) affects pregnancy outcomes and is the source of delivery complication among HIV infected pregnant women and newborns (Calvert \& Ronsmans, 2015; WHO, 2007; WHO, 2015). Studies shows that women with HIV are more likely to be infected with opportunistic infection due to compromised immunity (WHO, 2015; UNAIDS, 2012). Pregnant women who are HIV Infected are at risk of acquiring opportunistic infection caused by non-pathogens and pathogens bacteria, fungus and virus (WHO, 2015; WHO, 2007; UNAIDS, 2012).

The OIs may have indirect effect on the natural history of pregnancy, because adverse pregnancy outcomes and complications are more common among women with advanced HIV infection, and with severe and acute opportunistic OIs (Calvert \& Ronsmans, 2015). The unfavorable pregnancy outcomes such as preterm delivery and HIV transmission from mother to child have been reduce due to antenatal prophylactic treatment using antiretroviral therapy (ART), yet adverse pregnancy outcome such as stillbirth and underweight baby still remain as issues of public health importance among pregnant women infected with HIV (Ngarina et al., 2014; Aniji et al., 2013; Watts et al., 2013; Short et al., 2014). 
DOI: $10.21522 /$ TIJPH.2013.05.04.Art051

ISSN: $2520-3134$

Researches indicate that severely immune-compromised women are at risk of pregnancy complications and adverse obstetric outcomes (Calvert and Ronsmans, 2015; Reitter et al., 2014; Ajenifuja et al., 2010; Kupka et al., 2009). The HIV infection is responsible for about 13 million stillbirths, which is $11 \%$ of live births each year worldwide, while most of these stillbirths are diagnosed in developing countries (Slyker et al., 2014). More than one-fourth of stillbirth are found in Sub-Saharan (Kumar, 2016; Slyker et al., 2014). Tanzania has more than $7 \%$ of pregnant women infected with HIV (Tanzania PMTCT, 2016). Slyker et al., (2014) found higher risk of preterm deliveries among pregnant women infected with HIV.

The degree of exposure to the pathogens and immunity of the pregnant women when exposed and the use of prophylactic ARV determine the development of OIs (WHO, 2015; UNAIDS, 2012). The HIV infected Pregnant women that develop OIs may have not been using ARV prophylaxis properly causing rapid replication of HIV leading to higher viral road that weakened the immunity (WHO, 2015; WHO, 2007; UNAIDS, 2012).

The maternal treatment using antiretroviral therapy (ART) has been associated with significant increase of CD4 counts and reduction of viral load, resulting into improvement of maternal health and suppression of OIs (Kilewo et al., 2009; WHO, 2015; Suksomboon et al., 2007). The ART reduce viral load through suppression of viral replication, which reduces number of virus in the blood plasma and improve health status of pregnant mother (Siegfried et al., 2011; WHO, 2015; Suksomboon et al., 2007). Reduced virus in blood offer protection in transmission of HIV infection from a mother to a new born, but also leaves room for rebuild up of immunity (Siegfried et al., 2011; Moodley \& Wennberg, 2005; Tanzania PMTCT, 2016). Women that adhere to ART do not develop opportunistic infections, while the absence of clinical symptom is one of the indicators of good health and adherence to treatment (WHO, 2015; Tanzania PMTCT, 2016; Hill et al., 2013). The non-adherence to ART among pregnant women increases virus production in the blood, development of OIs, and reduces, fetus protection from being infected with HIV during pregnancy and delivery ( Hill et al., 2013; Kilewo et al., 2009; Kowalska et al., 2003; Suksomboon et al., 2007).

OIs are one of the main causes of poor health status, pregnancy complication and death among women infected with HIV throughout the world (WHO, 2015). The availability of ART prophylaxis has reduced the occurrence OIs for certain pregnant women who attend and access medication at antenatal clinics, but for those pregnant women without access to maternal care have OIs and adverse pregnancy outcomes (Calvert and Ronsmans, 2015; Ngarina et al., 2014; WHO, 2015; UNAIDS, 2012; ).

The most common OIs are herpes zoster, disseminated Mycobacterium avium complex (MAC) infection Candida esophagitis, Tuberculosis, Pneumocystis carinii pneumonia (PCP), Cryptococcus, kaposi sarcoma, and cytomegalovirus (CMV) (WHO, 2015;WHO, 2007). This study looks at the most common clinical symptoms representing those OIs.

Thus, this research was conducted to assess the prevalence of opportunistic Infection and associated pregnancy complication among HIV Positive Pregnant women delivering in government hospitals, Dar es salaam, Tanzania.

\section{Procedures and method}

The cross sectional descriptive study design was used to collect data from HIV infected women immediately after giving birth in Dar es Salaam government hospitals providing obstetric services. The Government hospitals were selected based on the fact that they have records of higher number of pregnant women attending these facilities for delivery services compared to other hospitals.

Participants were obtained from maternity wards among women who just completed giving birth. The HIV status of a woman was obtained from delivery register or antenatal cards. The HIV infected woman was who just delivered was approached by a research assistant to determine her eligibility and recruited into the study if she was eligible. Excluded were women with medical conditions that needed emergency treatments, those persistent vomiting that were unable to speak, and women in severe illness. Women that agreed to take part in the study were directed to interviewers for the consent process. Informed consent 
was administered in local language. Individuals that consented to participate were required to undergo clinical assessment by clinician and then to provide self-report interview to identify and disclosure of opportunistic infection. The checklist form for opportunistic infections was prepared based on WHO guideline (WHO 2015; WHO, 2007). The checklist collected information on the demographic characteristic, clinical symptom of opportunistic infection and pregnancy complication. The demographic variables included; age, marital status, education level, and maternal characteristic of number of births. The pregnancy complication or outcome variables collected including; stillbirth, preterm delivery, baby weight, and vaginal tears. The participants were screened for presence or absence of OIs clinical symptom. The following OIs clinical symptoms were analyzed with their respective stages.

The OIs clinical symptoms of HIV early stage (WHO clinical stages1 and 2) were;

1. Unexplained recurring fever,

2. Persistent Chill,

3. Recurrent skin rashes,

4. Persistent profuse night sweats,

5. Productive cough for more than two weeks,

6. persistent muscle aches,

7. Recurrent sore throat,

8. Frequently fatigue,

9. Persistent swollen lymph nodes,

10.Persistent mouth ulcers (WHO, 2015; WHO, 2007, UNAIDS 2012).

The OIs clinical symptoms in late HIV stage, (WHO clinical stages3 and 4) assessed were;

1. Unexplained rapid weight loss $>10 \%$,

2. Extreme and unexplained tiredness,

3. Unexplained prolonged swollen lymph glands in the armpits, groin or neck (lymphadenopathy),

4. Unexplained chronic diarrhea for more that 1 month,

5. Recurrent sores of the mouth, anus, or genitals,

6. Recurrent severe pneumonia,

7. Recurring fever with profuse night sweats

8. Unexplained persistent red, brown, pink or purple blotches on or under the skin or inside the mouth, nose or eyelids,

9. Recurrent memory loss, depression and neurological disorders, and

10.Kaposi's sarcoma or lymphoma (WHO, 2015; UNAIDS, 2012; WHO, 2007).

Each question of the OIs checklist described above was marked "Yes" if OIs clinical symptom was present or "No" if there was none.

With regard to this study, OIs clinical symptoms that were persistent during pregnancy period till delivery, pregnancy complication or outcome during delivery and demographic variables were recorded and included for analysis.

\section{Ethical consideration}

The Coordinating Committee of National Institute for Medical Research (NIMR Tanzania), approved this research. The informed consent was administered to all women participants that were interested to be part of this study.

\section{Data analysis}

The paper checklist was used, which was then entered into Epidata software entry screen. The complete set of data from the software was then transferred to SAS version 9.4 for analysis. In this study we were interested with the prevalence of OIs and associated pregnancy complication or outcome in HIV Positive Pregnant women giving birth and also their associations with demographic characteristics. To determine association between variables, frequencies tables and cross tabulations were used, while 
DOI: $10.21522 /$ TIJPH.2013.05.04.Art051

ISSN: $2520-3134$

categorical data was analyzed using Chi- squire test for the purpose of testing statistical significance between these variable associations. The $\mathrm{P}$-values $<0.05$ was considered significant association.

\section{Results}

Among the participants enrolled, $22(20.9 \%)$ were aged between 18-25 years, 79 (75. 2\%) aged between 26- 40, and $4(3.8 \%)$ were women between the age of 41-44 (Table 1). The result indicates that $19(18.1 \%)$ had delivered once, 76(72.3\%) delivered between 2-4 times and 10(9.5\%) of them had 5-9 births (Table1). More than half 62(59\%) of them achieved primary level education, while $28(26.6 \%)$ completed secondary level education, while 13 (12.3\%) had not attended any formal education or school, and only 2(1.9\%) are college graduate (Table 1). Among them, $18(17.10 \%)$ stayed without a partner, and $87(82.8 \%)$ were living with their partners.

Among 105 women that participated in the study, 63(60\%) had common OIs clinical symptoms, while only, 42(40\%) had not (Table 1). Among those with OIs, 15(14.2\%) were women aged 18-25, while 47(44.7\%) were women aged 26-40 and $1(0.9 \%)$ was a women aged 41-44 (Table 1). Women with single birth that had OIs were 11(10.48\%), while women with 2-4 births with OIs were 47(44.7\%), and women with more than 5 births with OI were 5(4.76\%) women with OIs. The OIs was diagnosed in 2(1.9\%) women of college education, 16(15.24\%) women of secondary education, 37(35.24\%) women that completed primary education and in 8 (7.6\%) women without formal education (Table 1). We diagnosed OIs in $11(10.4 \%)$ women living without their partners, while 52(49.5\%) women living with their partners had OIs. Almost a quarter, 25(23.8\%) women aged 26-40, and 26(24.7\%) women with 2-4 birth, presented with symptoms found in both stages of early and late HIV infection, while $27(25.7 \%)$ women living with their partners also had OIs symptoms of HIV infection of late and early stages(Table 1).

More women, 47(44.7\%) of age group 26-40 had OIs compared to 15(14.2\%) women age group of 1825 years and $1(0.95 \%)$ women with age group of $41-44$ years, although the associations were not significant (Table1). The OIs were more diagnosed in 47(44.7\%) women with 2-4 births than, 11(10.4\%) women of single birth and 5(4.7\%) women with 5-9 births. The observed associations were not significant (Table1). Women with primary level education were more, 37(35.2\%) found with OIs than groups of women from other education levels of; college 2 (1.9\%), secondary education 16(15.2\%) and these with no formal education 8 (7.6\%) however the associations were not significant (Table1). More participants, $52(49.5 \%)$ that were living with their partners had OIs compared to 11(10.4\%) participants living without partners, yet the association was not significant (Table 1).

Based on HIV stages, among 63 women that had OIs, 27 (42.8\%) had presented with only early HIV stage symptoms, and 4 (6.3\%) showed late HIV stage symptoms only, while 32 (50.7\%) had symptoms of both early and late HIV stages (Table 1). More 25(23.8\%)women age 26-40 reported OIs symptoms of both HIV stages than $7(6.6 \%)$ age groups of 18-25, although the association was not significant (Table1). Women with primary level education were more 18 (17.1\%) found with symptoms of both stages than women from other education levels of; college education $1(0.95 \%)$, secondary level $8(7.6 \%)$, and these with no formal education $5(4.7 \%)$ (Table1), the associations were not significant. The participants that were living with their partners had more $27(25.7 \%)$ presented with OIs symptoms under both HIV stages than 5(4.7\%) women who were living without partners, however the association was not significant (Table 1). More participants, 26(24.7\%) from 2-4 births had OIs presenting both HIV stages than 3(2.8\%) women groups of single birth and women with 5-9 births (Table1). The observed associations were not significant.

This study indicates that the most common OIs clinical symptoms in early HIV infection (WHO clinical stages 1 and 2) were; frequently fatigue 46(43.8\%), persistent profuse night sweats 43(40.9\%), persistent muscle aches 41(39\%), and unexplained recurring fever 39(37.1\%) (Table2). The OIs clinical symptoms of late HIV stage symptoms, WHO clinical stages 3 and 4 that were most common among those participants are; extreme and unexplained tiredness 43(40.9\%), recurrent severe pneumonia 
$37(35.2 \%)$, recurring fever with profuse night sweats 33(31.4\%), and unexplained rapid weight loss $>10 \%$ 27(25.7\%) (Table2).

The findings show that 24(35.2\%) participants without recurrent severe pneumonia, 24(35.2\%), which is among the late HIV stage (WHO clinical stage $3 \& 4$ ) were slightly protected to developed vaginal tears during birth compared to 7 (18.9\%) women with recurrent severe pneumonia, P- Value $=0.0693$ (Table3). Women with recurrent memory loss, depression and neurological disorders had more, 5 (20.8\%) babies born with body weight below $2500 \mathrm{~g}$ (underweight) than $5(6.1 \%)$, from women without these symptoms, P- Value 0.0316 (Table3). The recurrent memory loss, depression and neurological disorders are among the OIs clinical symptoms for individual with HIV in late AIDS stage (WHO clinical stage 3 \&4). Other OIs clinical symptoms under this study had no significant associations with pregnancy complications under this research.

\section{Discussion}

This study was conducted in high HIV transmission area where almost $7 \%$ of pregnant women are infected with HIV (Tanzania PMTCT, 2016). More than half of participants showed OIs symptoms of both early and late HIV stages. This show that more women are developing OIs during pregnancy, which may increase transmission rate from mother to child (WHO, 2015; WHO, 2007, UNAIDS 2012). The presence of late HIV stage OIs symptoms is a red flag indicating escalating advancement of HIV infection among pregnant women that pose serious threat in maternal health. If the situation remained unchecked will jeopardize efforts toward elimination of HIV and fight against AIDS.

The increased number of women with OIs indicates that the OI is overwhelming as barrier to improving maternal health and prevention HIV transmission and inadequacy of antenatal prophylactic ARV programs.

The OIs symptoms were more observed in women age 26-40 compared to age groups of; 18-25 years and 41-44 years. Women with 2-4 birth had more identified with OIs than group of single birth, and women with 5-9 births. Women with primary level education were more found with OIs than groups of women from other education levels. The OIs clinical symptoms were more diagnosed among women with primary level education, the lowest formal education level in the country. The low level education may probably have affected the ability to understand HIV prevention strategies and the importance of using prophylactic ARV given at antenatal clinics. The low education level may have coupled with fear to disclose HIV status to get helps from family members, poverty and economic hardship that discouraged long-term adherence (Ngarina et al., 2014; Ngarina et al., 2013; Tanzania PMTCT, 2016). Many participants that were living with partners had OIs compared to women who were living without their partners. This phenomenon may have been contributed by women living with partners being not able to take drug to prevent their HIV status to be known to family members including their partners (Ngarina et al., 2014; Ngarina et al., 2013).

Among women who had OIs, nearly half of them had the following common OIs clinical symptoms; frequently fatigue, persistent profuse night sweats and extreme and unexplained tiredness, while one third of participants presented with; persistent muscle aches, unexplained recurring fever, recurrent severe pneumonia, and recurring fever with profuse night sweats. A quarter of them presented with unexplained rapid weight loss. The most common OIs clinical symptoms diagnosed which belongs to the late stage (WHO clinical stages 3 and 4) were; extreme and unexplained tiredness, recurrent severe pneumonia, recurring fever with profuse night sweats, and unexplained rapid weight loss $>10 \%$.

The OIs influence various pregnancy complications or outcomes. In our study, participants without recurrent severe pneumonia, which is among the late HIV/ AIDS stage (WHO clinical stage 3 \&4) are slightly more protected to develop vaginal tears during child birth than women with this OIs. Women with recurrent memory loss, depression and neurological disorders are more likely to give birth to underweight babies compared to women without these symptoms. The recurrent memory loss, depression and neurological disorders develop among HIV infected person during late AIDS stage, WHO clinical 
DOI: $10.21522 /$ TIJPH.2013.05.04.Art051

ISSN: $2520-3134$

stage 3 \&4 (WHO, 2015; WHO, 2007, UNAIDS 2012). Other OIs symptoms had no significant association with pregnancy complications or outcomes.

Currently, antenatal clinic lacks a thoroughly clinical assessment that is important to identify and treat OIs. There is need to strengthen PMTCT services in Tanzania. This study will inform the government and health care workers on the importance of policy change with respect to antenatal clinics to ensure thoroughly medical investigations in antenatal clinics and adequate antenatal programs and follow up of ART intake among pregnant women. A study on adherence to ART is important in this situation.

\section{Conclusion}

More than half of participants had OIs. Nearly a half of participants with OIs presented with clinical symptoms of frequently fatigue, persistent profuse night sweats, and extreme and unexplained tiredness that needed thoroughly medical investigations and treatments. Having low level of education and living with partners are risk factor to develop OIs. The recurrent severe pneumonia is a risk factor for develop vaginal tears during child birth, while recurrent memory loss, depression and neurological disorders are risk factors to give birth to underweight baby. The increased OIs is bringing overwhelming barrier to improving maternal health and indicates inadequacy of antenatal prophylactic ART programs. There is need for policy change to ensure adequate medical investigations in antenatal clinics and adequate antenatal programs and follow up of ART intake among pregnant women infected with HIV.

\section{References}

[1].Aniji C D,1 FCOG (SA); O A Towobola,1 PhD; M E Hoque,2 MSc; T J Mashamba,1 MB ChB; S Monokoane,1 FCOG (SA) (2013). Impact of antiretroviral therapy on pregnancy outcomes. S Afr J HIV Med 2013; 14(4):176178. DOI:10.7196/SAJHIVMED.834.

[2].Calvert C, Ronsmans C. (2015). Pregnancy and HIV disease progression: a systematic review and meta-analysis. Journal of Tropical Medicine and International Health, 20(2):122-45. Retrieved June 5, 2016, from PubMed.

[3].Kumar, N. (2016). Postpartum Hemorrhage; a Major Killer of Woman: Review of Current Scenario. Obstetrics \& Gynecology International Journal, 4(4). Published online

[4].Kilewo Charles, Katarina Karlsson, Matilda Ngarina, Augustine Massawe, Eligius Lyamuya, Andrew Swai, Rosina Lipyoga, Fred Mhalu, Gunnel Biberfeld. Prevention of Mother to Child Transmission of HIV-1 through Breastfeeding by Treating Mothers with triple Antiretroviral Therapy in Dar es Salaam, Tanzania: The Mitra Plus study. Journal of Acquired Immune Deficiency Syndromes. 2009, 53: 406-41.

[5].Kowalska A, Niemiec T, El Midaoui A, Burkacka E. Effect of antiretroviral therapy on pregnancy outcome in HIV-1 positive women. Med Wieku Rozwoj. 2003 Oct-Dec;7(4 Pt 1):459-68.

[6].Kupka, R., Kassaye, T., Saathoff, E., Hertzmark, E., Msamanga, G. I. And Fawzi, W. W. (2009). Predictors of stillbirth among HIV-infected Tanzanian women. Journal of Acta Obstetricia et Gynecologica Scandinavica, 88: 584-592. Retrieved June 5, 2016, from PubMed.

[7].Moodley J, Wennberg JL. HIV in pregnancy. Curr Opin Obstet Gynecol. 2005 Apr; 17(2):117-21.

[8].Ngarina Matilda, Rebecca Popenoe, Charles Kilewo, Gunnel Biberfeld, Anna Mia Ekström. Reasons for poor adherence to antiretroviral therapy postnatally in HIV-1 infected women treated for their own health: experiences from the Mitra Plus study in Tanzania. BMC Public Health. 2013, 13: 450.

[9].Ngarina M, Tarimo EAM, Naburi H, Kilewo C, Mwanyika-Sando M, Chalamilla G, et al. (2014) Women's Preferences Regarding Infant or Maternal Antiretroviral Prophylaxis for Prevention of Mother-To-Child Transmission of HIV during Breastfeeding and Their Views on Option B+ in Dar es Salaam, Tanzania. PLoS ONE 9(1): e85310. doi:10.1371/journal.pone.0085310.

[10]. Short C-ES, M Douglas, JH Smith and GP Taylor (2014) Preterm delivery risk in women initiating antiretroviral therapy to prevent HIV mother-to-child transmission. HIV medicine 201415, 233-238. DOI: 10.111/hiv.12083.

[11]. Tanzania PMTCT. National resource centre for prevention of mother to child HIV transmission (2016). Retrieved June 152016 from http://pmtct.or.tz/pmtct-tanzania/pmtct-in-tanzania/. 
[12]. Reitter A1, Stücker AU, Linde R, Königs C, Knecht G, Herrmann E, Schlößer R, Louwen F, Haberl A. Pregnancy complications in HIV-positive women: 11-year data from the Frankfurt HIV Cohort. HIV Med. 2014 Oct;15(9):525-36. doi: 10.1111/hiv.12142. Epub 2014 Mar 6.

[13]. Siegfried N1, van der Merwe L, Brocklehurst P, Sint TT. Antiretrovirals for reducing the risk of mother-tochild transmission of HIV infection. Cochrane Database Syst Rev. 2011 Jul 6;(7):CD003510. doi: 10.1002/14651858.CD003510.pub3.

[14]. Suksomboon N, Poolsup N, Ket-Aim S. Systematic review of the efficacy of antiretroviral therapies for reducing the risk of mother-to-child transmission of HIV infection. J Clin Pharm Ther. 2007 Jun; 32(3):293-311.

[15]. UNAIDS .2012. Joint United Nations Programme on HIV/AIDS (Global report: UNAIDS report on the global AIDS epidemic 2012. Retrieved May 17, 2016, from http://www.unaids.org/en/media/unaids/contentassets/documents/epidemiology/2012/gr2012/20121120_UNAIDS_ Global_Report_2012_with_annexes_en.pdf.

[16]. Watts DH1, Williams PL, Kacanek D, Griner R, Rich K, Hazra R, Mofenson LM, Mendez HA; Pediatric HIV/AIDS Cohort Study (2013). Combination antiretroviral use and preterm birth. J Infect Dis. 2013 Feb 15; 207(4):612-21. doi: 10.1093/infdis/jis728.

[17]. WHO (2007). Who case definitions of HIV for surveillance and revised clinical staging and immunological classification of HIV-related disease in adults and children. Retrieved June 152016 from http://www.who.int/hiv/pub/guidelines/HIVstaging150307.pdf.

[18]. WHO (2015) Guideline on when to start antiretroviral therapy and on pre Exposure prophylaxis for HIV (pdf). Retrieved June 152016 from http://www.who.int/hiv/pub/guidelines/clinicalstaging.pdf).

Table1. The prevalence of OIs and HIV stages based on demographic variables

\begin{tabular}{|c|c|c|c|c|c|c|c|}
\hline \multirow[t]{2}{*}{ Variable } & \multirow[t]{2}{*}{ Response } & \multirow{2}{*}{$\begin{array}{l}\text { Without } \\
\text { OIs } \\
(\mathrm{n}, \%)\end{array}$} & \multicolumn{4}{|l|}{ With OIs } & \multirow[b]{2}{*}{$P$ value } \\
\hline & & & $\begin{array}{l}\text { Early stage } \\
\text { symptoms } \\
\text { only } n,(\%)\end{array}$ & $\begin{array}{l}\text { Late stage } \\
\text { symptoms } \\
\text { only } n,(\%)\end{array}$ & $\begin{array}{l}\text { Both } \\
\text { stages } \\
\mathrm{n},(\%)\end{array}$ & Total & \\
\hline \multirow[t]{3}{*}{ Age group } & $18-25$ & $7(6.67)$ & $7(6.67)$ & $1(0.95)$ & $7(6.67)$ & $15(14.29)$ & \\
\hline & $26-40$ & $32(30.48)$ & $19(18.1)$ & $3(2.86)$ & $25(23.81)$ & $47(44.77)$ & \\
\hline & $41-44$ & $3(2.86)$ & $1(0.95)$ & $0(0)$ & $0(0)$ & $1(0.95)$ & 0.7501 \\
\hline \multirow{3}{*}{$\begin{array}{l}\text { Number of } \\
\text { Births }\end{array}$} & 1 & $8(7.62)$ & $7(6.67)$ & $1(0.95)$ & $3(2.86)$ & $11(10.48)$ & \\
\hline & $2-4$ & $29(27.62)$ & $18(17.14)$ & $3(2.86)$ & $26(24.76)$ & $47(44.76)$ & \\
\hline & $5-9$ & $5(4.76)$ & $2(1.9)$ & $0(0)$ & $3(2.86)$ & $5(4.76)$ & 0.7195 \\
\hline \multirow{4}{*}{$\begin{array}{l}\text { Education } \\
\text { level }\end{array}$} & College & $0(0)$ & $1(0.95)$ & $0(0)$ & $1(0.95)$ & $2(1.9)$ & \\
\hline & Secondary & $12(11.43)$ & $7(6.67)$ & $1(0.95)$ & $8(7.62)$ & $16(15.24)$ & \\
\hline & Primary & $25(23.81)$ & $16(15.24)$ & $3(2.86)$ & $18(17.14)$ & $37(35.24)$ & \\
\hline & None & $5(4.76)$ & $3(2.86)$ & $0(0)$ & $5(4.76)$ & $8(7.62)$ & 0.9746 \\
\hline \multirow{2}{*}{$\begin{array}{l}\text { Mariage } \\
\text { status }\end{array}$} & No Partner & $7(6.67)$ & $5(4.76)$ & $1(0.95)$ & $5(4.76)$ & $11(10.47)$ & \\
\hline & With partner & $35(33.33)$ & $22(20.95)$ & $3(2.860$ & $27(25.71)$ & $52(49.52)$ & 0.9659 \\
\hline Prevalence & & $42(40)$ & & & & $63(60)$ & \\
\hline
\end{tabular}


DOI: $10.21522 /$ TIJPH.2013.05.04.Art051

ISSN: $2520-3134$

Table 2. The most common OIs clinical symptoms among HIV infected women giving birth in government hospitals

\begin{tabular}{|l|l|l|l|}
\hline Description of OIs based on HIV stages \\
\hline HIV stage & OIs symptoms & $\begin{array}{l}\text { Number } \\
(\mathrm{n})\end{array}$ & $\begin{array}{l}\text { Percentage } \\
(\%)\end{array}$ \\
\hline \multirow{2}{*}{$\begin{array}{l}\text { Early HIV stage } \\
\text { (WHO stage 1 \&2) }\end{array}$} & Frequently fatigue & 46 & 43.81 \\
\cline { 2 - 4 } & Persistent profuse night sweats, & 43 & 40.95 \\
\cline { 2 - 4 } & Persistent muscle aches & 41 & 39.05 \\
\cline { 2 - 4 } & Unexplained recurring fever & 39 & 37.14 \\
\hline \multirow{2}{*}{$\begin{array}{l}\text { Late HIV stage } \\
\text { (WHO stage 1 \&2) }\end{array}$} & Extreme and unexplained tiredness & 43 & 40.95 \\
\cline { 2 - 4 } & Recurrent severe pneumonia, & 37 & 35.24 \\
\cline { 2 - 4 } & $\begin{array}{l}\text { Recurring fever with profuse night } \\
\text { sweats }\end{array}$ & 33 & 31.43 \\
\cline { 2 - 4 } & Unexplained rapid weight loss >10\% & 27 & 25.71 \\
\hline
\end{tabular}


Texila International Journal of Public Health Volume 5, Issue 4, Dec 2017

Table3. The OIs and related pregnancy complication among HIV infected women delivering in hospitals of dar es salaam

\begin{tabular}{|c|c|c|c|c|c|c|c|c|c|}
\hline \multirow{2}{*}{ OIs Symptoms } & \multirow{2}{*}{$\begin{array}{l}\text { Sympto } \\
\text { ms } \\
\text { status }\end{array}$} & \multicolumn{8}{|c|}{ Pregnancy complication and outcomes developed } \\
\hline & & $\begin{array}{l}\text { Stillborn } \\
\text { baby (n) } \\
\%\end{array}$ & P-value & $\begin{array}{l}\text { Vaginal } \\
\text { tear } \\
\mathrm{n}(\%)\end{array}$ & $\begin{array}{l}\mathrm{P}- \\
\text { value }\end{array}$ & $\begin{array}{l}\text { Preterm } \\
\text { deliveryn } \\
(\%)\end{array}$ & $\begin{array}{l}\mathrm{P}- \\
\text { value }\end{array}$ & $\begin{array}{l}\text { Baby } \\
\text { Weight } \\
\text { below } \\
2.5 \mathrm{~kg} \mathrm{n} \\
(\%)\end{array}$ & $\begin{array}{l}\mathrm{P} \text { - } \\
\text { value }\end{array}$ \\
\hline \multirow[t]{2}{*}{ Frequently fatigue $*$} & No & (2) 3.39 & \multirow[t]{2}{*}{0.7992} & $\begin{array}{l}(20) 33.9 \\
0\end{array}$ & & $6(10.1)$ & \multirow[t]{2}{*}{$\begin{array}{l}0.798 \\
5\end{array}$} & (7)11.86 & \multirow[t]{2}{*}{$\begin{array}{l}0.354 \\
8\end{array}$} \\
\hline & Yes & (2) 4.35 & & $\begin{array}{l}(11) 23.9 \\
1\end{array}$ & $\begin{array}{l}0.475 \\
6 \\
\end{array}$ & $4(8.7)$ & & \multirow[t]{2}{*}{$\begin{array}{l}\text { (3) } 6.52 \\
(8) 12.50\end{array}$} & \\
\hline \multirow[t]{2}{*}{$\begin{array}{l}\text { Persistent muscle } \\
\text { aches* }\end{array}$} & No & (2) 3.13 & \multirow[t]{2}{*}{0.6471} & $\begin{array}{l}(23) 35.9 \\
4\end{array}$ & & $7(10.9)$ & \multirow[t]{2}{*}{$\begin{array}{l}0.537 \\
5\end{array}$} & & \multirow[t]{2}{*}{$\begin{array}{l}0.194 \\
3\end{array}$} \\
\hline & Yes & (2) 4.88 & & (8)19.51 & $\begin{array}{l}0.182 \\
1\end{array}$ & $3(7.3)$ & & (2) 4.88 & \\
\hline \multirow[t]{2}{*}{$\begin{array}{l}\text { Persistent profuse night } \\
\text { sweats* }\end{array}$} & No & (2) 3.23 & \multirow[t]{2}{*}{0.1408} & $\begin{array}{l}(20) 32.2 \\
6\end{array}$ & & $6(9.6)$ & \multirow[t]{2}{*}{$\begin{array}{l}0.948 \\
3\end{array}$} & (6) 9.68 & \multirow[t]{2}{*}{$\begin{array}{l}0.948 \\
7\end{array}$} \\
\hline & Yes & (2) 4.65 & & $\begin{array}{l}(11) 25.5 \\
8\end{array}$ & $\begin{array}{l}0.715 \\
0\end{array}$ & $4(9.3)$ & & (4) 9.30 & \\
\hline \multirow[t]{2}{*}{$\begin{array}{l}\text { Unexplained recurring } \\
\text { fever* }\end{array}$} & No & (2) 3.03 & \multirow[t]{2}{*}{0.5874} & $\begin{array}{l}(20) 30.3 \\
0\end{array}$ & & $5(7.5)$ & \multirow[t]{2}{*}{$\begin{array}{l}0.376 \\
4\end{array}$} & $(60) 9.09$ & \multirow[t]{2}{*}{$\begin{array}{l}0.844 \\
2\end{array}$} \\
\hline & Yes & (2) 5.13 & & $\begin{array}{l}(11) 28.2 \\
1\end{array}$ & $\begin{array}{l}0.961 \\
3 \\
\end{array}$ & $5(12.8)$ & & (4) 10.26 & \\
\hline \multirow{2}{*}{$\begin{array}{l}\text { Recurrent sores of the } \\
\text { mouth, anus, or } \\
\text { genitals* }\end{array}$} & No & (2) 2.82 & \multirow[t]{2}{*}{0.4426} & $\begin{array}{l}(22) 30.9 \\
9\end{array}$ & $\begin{array}{l}0.395 \\
5\end{array}$ & $6(8.4)$ & \multirow[t]{2}{*}{$\begin{array}{l}0.588 \\
3\end{array}$} & (6) 8.45 & \multirow[t]{2}{*}{$\begin{array}{l}0.588 \\
3\end{array}$} \\
\hline & Yes & (2) 5.88 & & (9)26.47 & & $4(11.7)$ & & (4)11.76 & \\
\hline \multirow[t]{2}{*}{$\begin{array}{l}\text { Extreme and } \\
\text { unexplained tiredness+ }\end{array}$} & No & (2) 3.23 & \multirow[t]{2}{*}{0.7075} & $\begin{array}{l}(22) 35.4 \\
8\end{array}$ & & $4(6.4)$ & \multirow[t]{2}{*}{$\begin{array}{l}0.197 \\
8\end{array}$} & (6)9.68 & \multirow[t]{2}{*}{$\begin{array}{l}0.948 \\
7\end{array}$} \\
\hline & Yes & (2) 4.65 & & (9)20.93 & $\begin{array}{l}0.247 \\
8 \\
\end{array}$ & $6(13.9)$ & & (4) 9.30 & \\
\hline \multirow[t]{2}{*}{$\begin{array}{l}\text { Recurrent severe } \\
\text { pneumonia+ }\end{array}$} & No & (2) 2.94 & \multirow[t]{2}{*}{0.5286} & $\begin{array}{l}(24) 35.2 \\
9\end{array}$ & $\begin{array}{l}\mathbf{0 . 0 6 9} \\
3\end{array}$ & $6(8.8)$ & \multirow[t]{2}{*}{$\begin{array}{l}0.740 \\
3\end{array}$} & (7)10.29 & \multirow[t]{2}{*}{$\begin{array}{l}0.715 \\
5\end{array}$} \\
\hline & Yes & (2) 5.41 & & (7)18.92 & & $4(10.8)$ & & (3) 8.11 & \\
\hline
\end{tabular}


DOI: $10.21522 /$ TIJPH.2013.05.04.Art051

ISSN: $2520-3134$

\begin{tabular}{|c|c|c|c|c|c|c|c|c|c|}
\hline \multirow[t]{2}{*}{$\begin{array}{l}\text { Recurring fever with } \\
\text { profuse night sweats+ }\end{array}$} & No & (4) 5.56 & \multirow[t]{2}{*}{0.1674} & $\begin{array}{l}(23) 31.9 \\
4\end{array}$ & \multirow[t]{2}{*}{$\begin{array}{l}0.724 \\
2\end{array}$} & $7(9.7)$ & \multirow[t]{2}{*}{$\begin{array}{l}0.918 \\
5\end{array}$} & (6) 8.33 & \multirow[t]{2}{*}{$\begin{array}{l}0.539 \\
3\end{array}$} \\
\hline & Yes & (0)0.00 & & (8) 24.24 & & $3(9.0)$ & & (4)12.12 & \\
\hline \multirow[t]{2}{*}{$\begin{array}{l}\text { Unexplained rapid } \\
\text { weight loss }>10 \%+\end{array}$} & No & (2) 2.56 & \multirow[t]{2}{*}{0.2572} & $\begin{array}{l}(23) 29.4 \\
9\end{array}$ & \multirow[t]{2}{*}{$\begin{array}{l}0.953 \\
0\end{array}$} & $7(8.9)$ & \multirow[t]{2}{*}{$\begin{array}{l}0.744 \\
4\end{array}$} & (7)8.97 & \multirow[t]{2}{*}{$\begin{array}{l}0.744 \\
4\end{array}$} \\
\hline & Yes & (2) 7.41 & & (8)29.63 & & $3(11.1)$ & & (3)11.11 & \\
\hline \multirow{2}{*}{$\begin{array}{l}\text { Recurrent memory loss, } \\
\text { depression and } \\
\text { neurological disorders } \\
+\end{array}$} & No & (2) 2.47 & \multirow[t]{2}{*}{0.1875} & $\begin{array}{l}(25) 30.8 \\
6\end{array}$ & \multirow[t]{2}{*}{$\begin{array}{l}0.507 \\
8\end{array}$} & $6(7.4)$ & \multirow[t]{2}{*}{$\begin{array}{l}0.174 \\
6\end{array}$} & (5)6.17 & \multirow[t]{2}{*}{$\begin{array}{l}0.031 \\
6\end{array}$} \\
\hline & Yes & (2) 8.33 & & (6)25.00 & & $4(16.6)$ & & (5)20.83 & \\
\hline
\end{tabular}

* HIV Early stage symptoms (WHO clinical stage 1\&2), + HIV Late stage symptoms (WHO clinical stage 3\&4). 